\title{
Medieval Treatises on Money
}

Five German monetary treatises written in the seventeenth century have reached the Business Historical Society through the generosity of Walter T. Rosen, Partner in Ladenburg, Thalman $\&$ Co. of New York. These books together with a late seventeenth century statement of English mercantilist theory were formerly in the Seligman collection.

Among the greatest difficulties in medieval trade were the variety and unstable value of the coins used in exchange. Variety was due to production of coins by hundreds of small localities - a condition which was of course obviated with the growth of nation states and coinage monopoly.

Monetary depreciation, according to J. M. Keynes in "Monetary Reform," is continuous for two reasons: the financial necessities of governments and the political influence of the debtor class. In the undeveloped system of medieval coinage there were additional factors - the deficient technique of minting which resulted in varying weights for the coins (this was particularly true of the smaller coins) and abrasion from ordinary use, as well as intentional abrasion commonly called "clipping." In the thirteenth and fourteenth centuries debasement of the silver currency was so great that gold came generally to take its place - while in the fifteenth century for the same reason and also the increase in German production of silver, silver was reëstablished to its former position in international trade.

From the fourteenth century two types of gold coins - the ducat and the gold gulden - were important in Germany's trade. According to an imperial ordinance of 1559 and unchanged until the eighteenth century, the exchange basis of the two coins was Ioo ducats to 137 gold gulden. In reality, however, the ratio varied from 120 to 164 gulden per 100 ducats during the seventeenth century alone.

The latest volume of this collection, "Münz Tractat," by C. L. Lucio and published about 1695 is a monetary treatise on the appreciation and depreciation of the gulden from 1676 to 1691 . A large part of the book is devoted to facsimiles of the numerous kinds of coins used in the German states and the texts of the monetary ordinances for the period. 


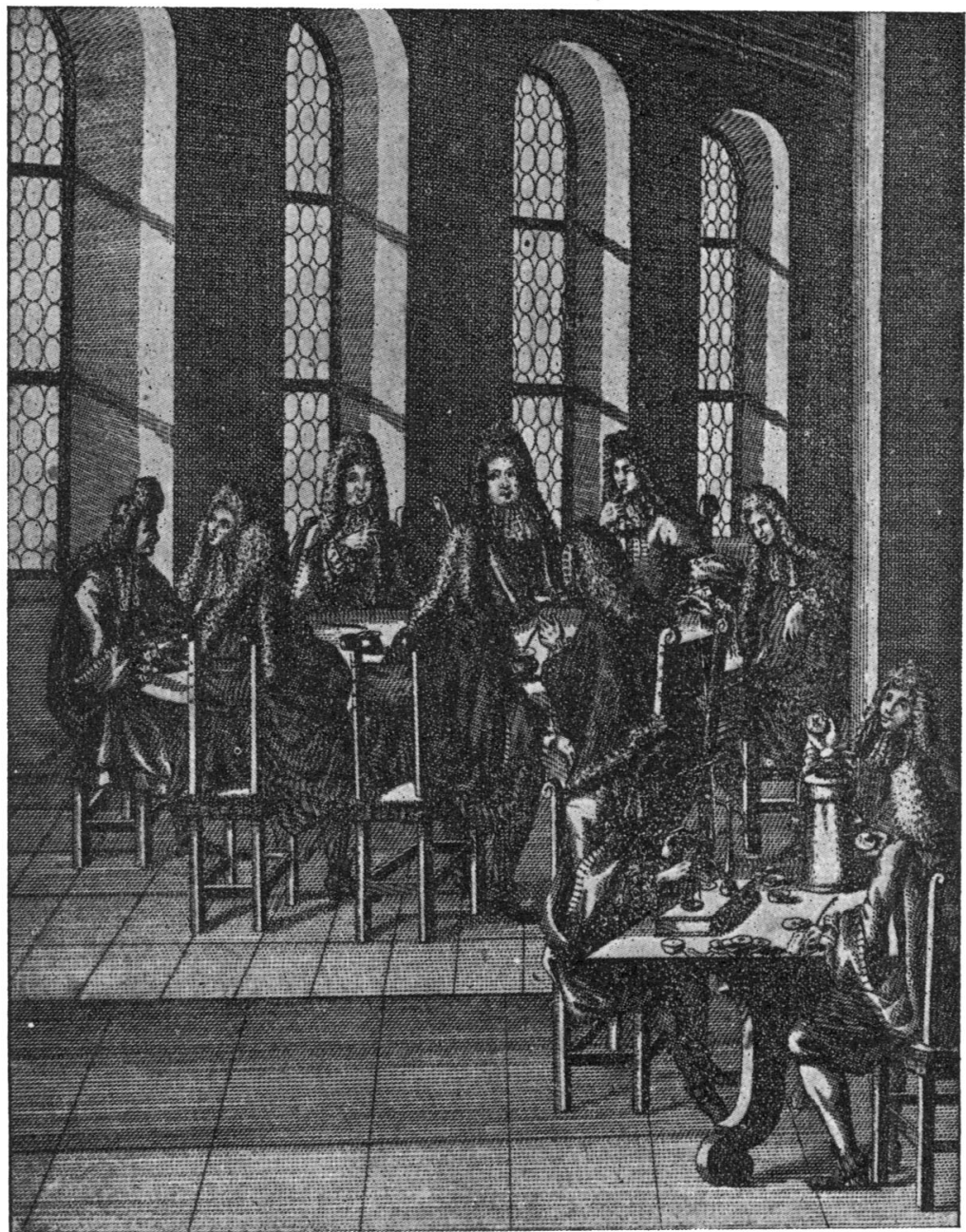

WEIGHING COINS IN THE SEVENTEENTH CENTURY

Frontispiece of Lucio's "Münz Tractat” (1695) 
The remaining German books are pamphlets dealing with particular questions which appeared important during the seventeenth century. One pamphlet appearing in 1624 dealt with the question of whether a debtor who had received gold standard coins of the realm could repay his debt in debased coinage and the author quotes imposing Latin passages to support his thesis that one should not. Another treatise appearing in I623 contains the "kurzes aber doch gründlichs Bedencken" on whether a man who had purchased a yearly pension could be expected to accept the same money which has since depreciated. A fourth pamphlet also treats of these monetary problems.

The most valuable book of this group is an expression of English mercantilism written at the height of this theory's popularity. It is, according to the unknown author, "A Discourse of Trade, Coyn, and Paper Credit: and of Ways and Means to Gain, and Retain Riches." Nations may be considered as great families, or merchants, or traders in their relations with one another. If one nation does not export goods in payment for goods imported, then as in the trade among individuals, there must be a movement of bullion. Those trades are good which encourage exports, those dis. advantageous which cause imports. The author admits gold and silver are only commodities which "cannot afford us any increase while kept within the Kingdom" yet he insists that it is "that in which the Riches of Nation doth so much consist" and vaguely substantiates this remark with the statement that gold and silver are "so necessary for the Payment of Fleets and Armies, and carrying on of Commerce, that we cannot be Safe, nor Rich, without it."

\section{Evidence of the Putting-Out System in America}

AN old hand-worn brown leather book has come into the hands of the Business Historical Society on the varied business activities of a New Englander for the period 1837 to 1857 . We are indebted to Edgar A. Clarke of New Hartford, Connecticut, for this rarity.

Anthony Baker, who kept the book, evidently began his career as a tanner and mâker of leather goods. Hides were probably brought in by the neighboring farmers to New Hartford, and boots, 